一鹿児島県一

\title{
$20 \mathrm{~kW}$ 大電力水銀ラプンによる \\ 日本石油基地(株)喜入基地さん橋の照明
}

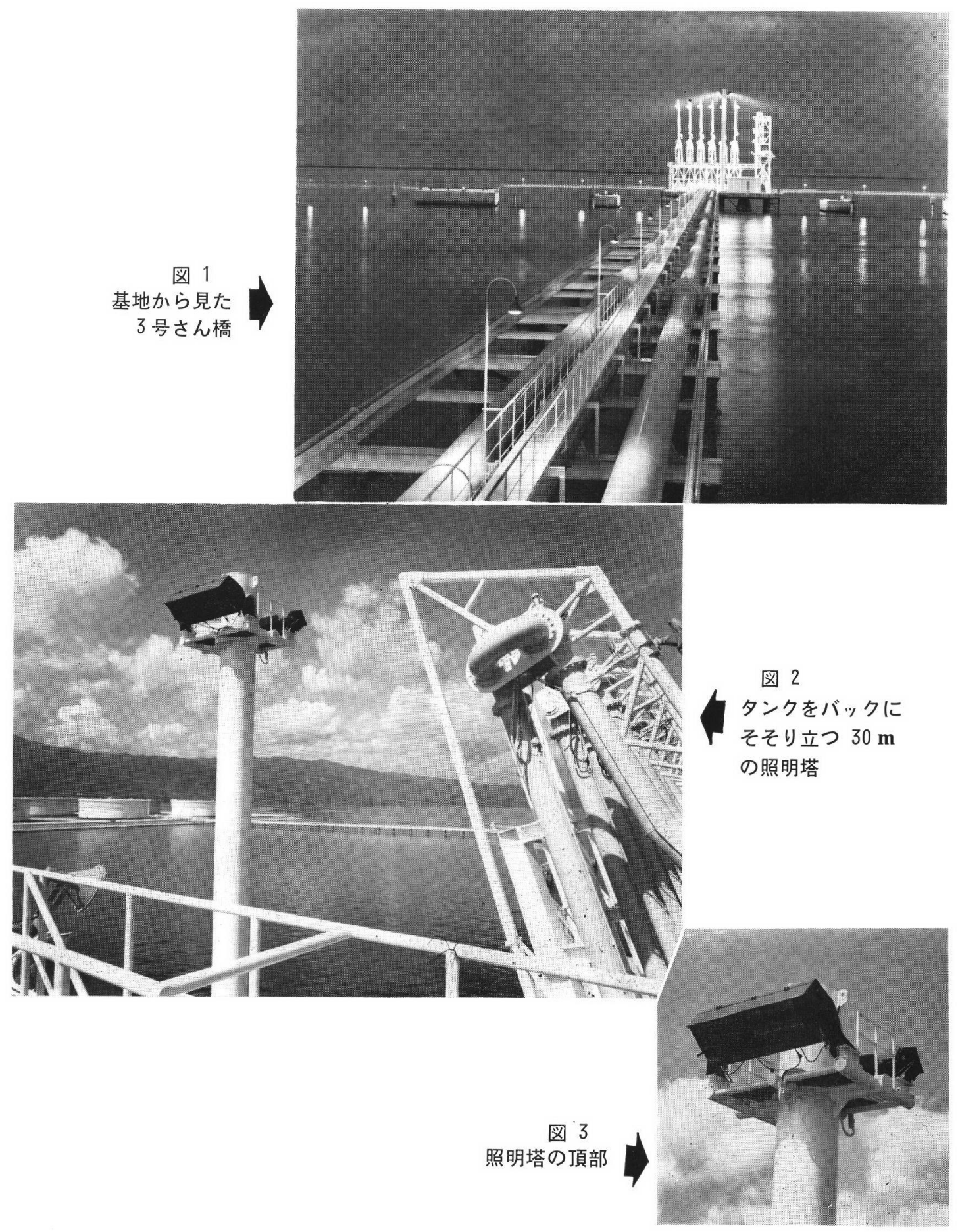


原油輸送の合理化から最近のタンカーは大型化の傾向 にあるが，その荷揚げと備蓄を目的とした石油基地が鹿 児島県喜入町に完成した. 従来大型タンカーの夜間の接 岸は注とんど行なわれていなかったが, この喜入基地で は荷揚げ能率の向上をめざし, $20 \mathrm{~kW}$ 大電力水銀ランプ を設備し，夜間での作業を可能にした（図 1).

\section{施 設 の 概 要}

$$
\begin{aligned}
& \text { 敷地面積 } 963,000 \mathrm{~m}^{2} \\
& \text { さん橋 } 2 \text { 号さん橋 } 15 \text { 万トンドルフィン(出荷用) } \\
& 3 \text { 号さん橋 } 45 \text { 万トンドルフィン（出入荷 } \\
& \text { 用） } \\
& \text { ローディングアーム } 12 \text { インチ } 4 \times 5 \text { 連( } 2 \text { 号さん橋) } \\
& 12 \text { インチ } 4 \times 6 \text { 連 ( } 3 \text { 号さん橋) } \\
& \text { タンク 原油タンク } 12 \text { 基 }(10 \text { 万 } \mathrm{kl}) \text { 注か } 3 \text { 基 }
\end{aligned}
$$

\section{照 明 設 備}

さん橋の照明は,

（1）けい船設備の範囲が大きいこと.

（2）船の大型化に伴い, 荷役後の船位の差があるので 高い光源の位置が要求されること.

（3）危険蒸気の発生を考虑して，光源までの距離が十 分にあること.

(4) 本来の海岸線よりも $1.6 \mathrm{~km}$ も沖合に設置す るために, 秒速 $80 \mathrm{~m}$ の風にも耐える構造であるこ と.

（5）したがって多灯方式を避け，大光源の単一灯 具がのぞあしく，かつ保守が容易なこと。

の 5 項目の諸条件を考慮し, 高さ $30 \mathrm{~m}$ の円筒照明 柱に $20 \mathrm{~kW}$ 大電力水銀 ランプ 投光器を搭載した （図 2，図 3). 照明塔は 2 号さん橋に 1 基， 3 号さ 几橋に 1 基設置され，その 1 基注さ $20 \mathrm{~kW}$ 水銀 ランプ投光器を 2 台ずつ合計 4 台取り付け, 照射角 度は鉛置方向より $30^{\circ}$ である. $20 \mathrm{~kW}$ 大電力水銀 ランプの特性を 表 1 に, 投光器 1 台の照度分布図 を図 4 に，さん橋の照度分布を図 5 に示す。

\begin{tabular}{|c|c|c|c|}
\hline 形 名 & $\mathrm{H} 20 \mathrm{KL}$ & 形 名 & $\mathrm{H} 20 \mathrm{~K} \mathrm{~L}$ \\
\hline ランプ電力 & $20(\mathrm{~kW})$ & ランプ電流 & 9.4 (A) \\
\hline 全長 & $2,150(\mathrm{~mm})$ & ランプ電圧 & $2,175(\mathrm{~V})$ \\
\hline 発 光 長 & $1,850(\mathrm{~mm})$ & $\begin{array}{l}\text { 全 充 束 } \\
\text { 率 }\end{array}$ & $\begin{aligned} 1,200,000 & (\mathrm{~lm}) \\
60 & (\mathrm{~lm} / \mathrm{W})\end{aligned}$ \\
\hline 管 外 径 & $46(\mathrm{~mm})$ & 寿 & $5,000(\mathrm{~h})$ \\
\hline 電源電圧 & $3,300(\mathrm{~V})$ & 点灯方位 & 平 \\
\hline
\end{tabular}

このさん橋照明の添かに, 構内通路照明用として $80 \mathrm{~m}$ 間隔に $400 \mathrm{~W}$ 水銀ランプ 76 灯, 構内広場照明用として $400 \mathrm{~W}$ 水銀ランプ, 安全塔器具を 15 灯, 石油タンク照 明用として $1.5 \mathrm{~kW}$ よう素電球投光器 12 灯, またさん 橋までの $380 \mathrm{~m}$ の海上回廊には, $24 \mathrm{~m}$ ピッチで $100 \mathrm{~W}$

表 $120 \mathrm{~kW}$ 大電力水銀ランプ特性表
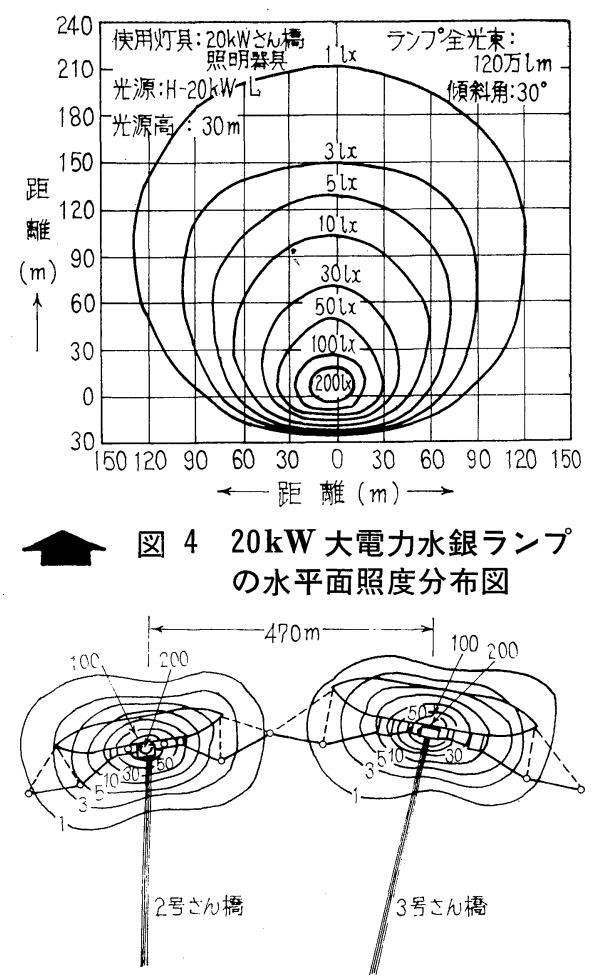

—図 5 さん橋の照度分布図

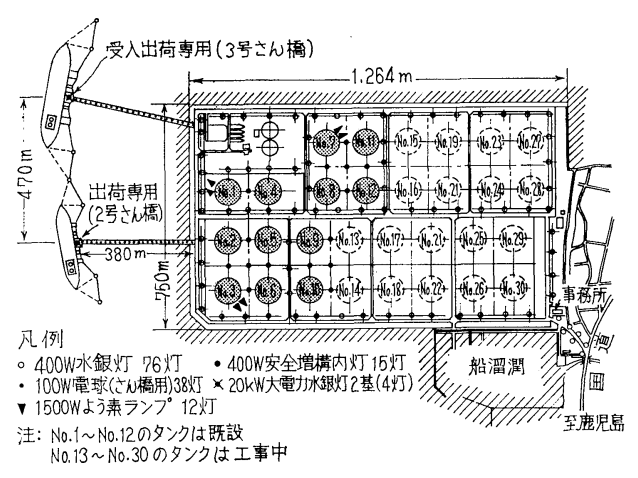

図 6 構内の照明器具配置図

電球が 38 灯などが設備されている. これらの照明器具 の配置を図 6 に示す。な拓構内つ照度は平均 $101 \mathrm{x}$ (設 計照度) である.

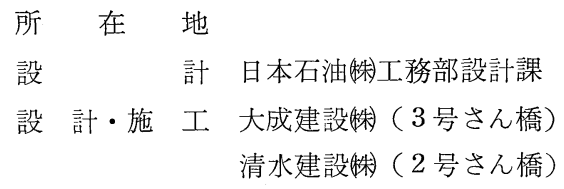

電気設備施工 九州電気工事( 秼), 東邦電気工業秼 照明設備製作 - 東京芝浦電気蛛, 東芝商事脒) 納入

（資料提供 東芝商事(㧣照明電材開発部） 正会員常川晃 


\section{昇降式ハイポールによる 横浜本牧市民プールの照明}

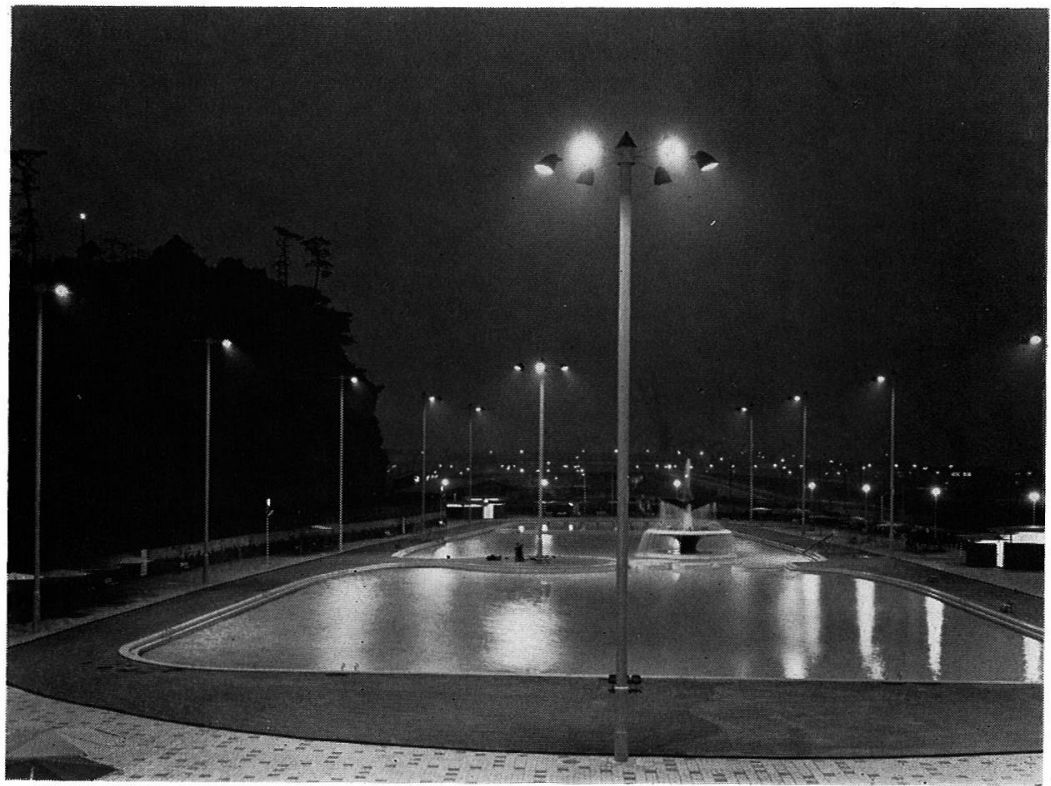

—図 1 市民プール全景

(遊泳プールより)

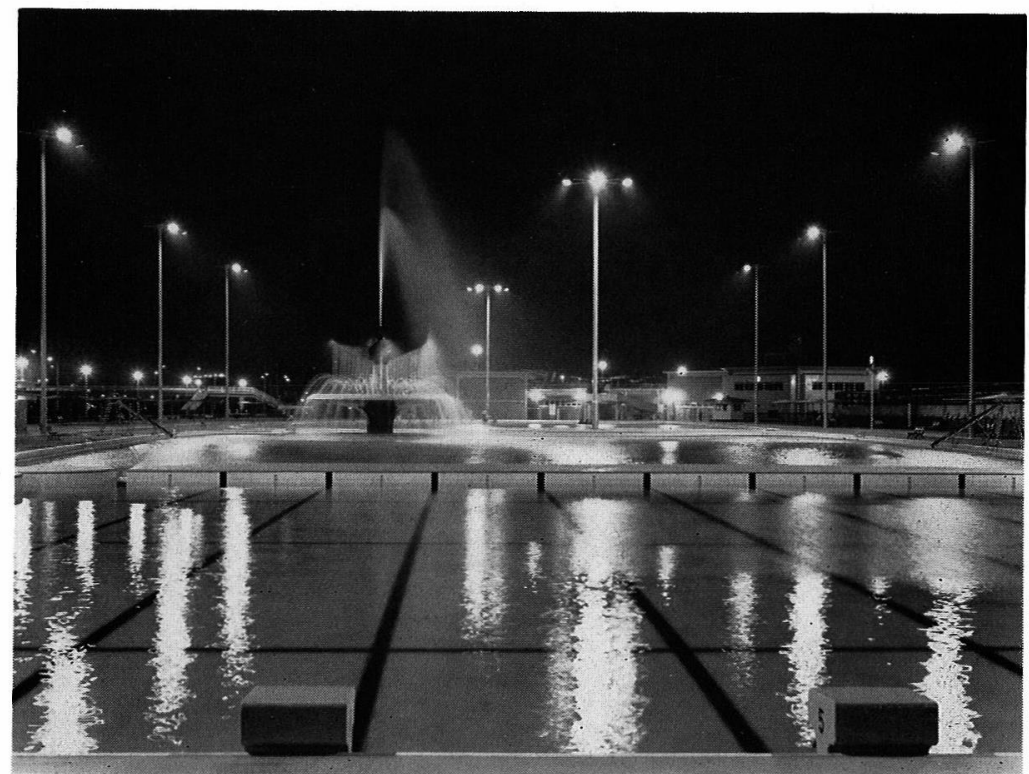

一一図 2 市民プール全景

$$
\text { (コースプールより) }
$$




\section{概}

要

横浜市が市民のレクリエーションセンターとして, 同 市中区の本牧埠頭産業用地化建設していた本牧市民公園 が完成した.

総面積 10 万平方メ一トルの中には，一度に 7,000 人 が泳げる本牧㠴民プールのほか, 運動公場, テニスュー ト，子供の遊び場，サイクリングロ一ドなど数多くの設 備をもつ総合レクリェーションセンターである.

ここで，本牧市民公園内の抋をなす市民プールの外 降式ハイポール照明を紹介する。

\section{照 明 設 備}

全国的に見られる屋外プールの照明方法は，投光器な ぞを利用した投光照明が一般的であるが，本牧们式ブー 儿では昇降式八イホール灯を採用し，遊泳者之観臨者一 の光源の水面よりの反射汇よるグレアを少なくした．

図1と図 2 にプールの全景を示与.

照明は, $700 \mathrm{~W}$ 汁い光水銀ランプ（HF 700）6灯用の $18 \mathrm{~m}$ 昇降式八イポール灯を 2 基，2灯用を 10 基設備し た. $700 \mathrm{~W} け い$ 光水銀ランプの 6 灯用はプールの中心部

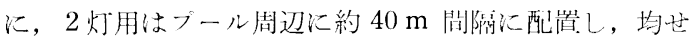
い度の向上をはかっている. 図 3 に6 灯用を, 図 4 に

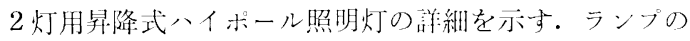
保守を考虑した灯具昇降式であるから，ランブ交換や火丁 具清掃の保守時には，地上 $2.5 \mathrm{~m}$ の高さ去で灯具が下け られる。

図 5 亿八イポール照明灯の配置と, 設初当初の倠度 分布を示す。

$18 \mathrm{~m}$ のハイポール照明灯は，咟閒の美観とともに， 夜間には，プール全体が設備当初平均 $65.11 \mathrm{x}$ の明るさ

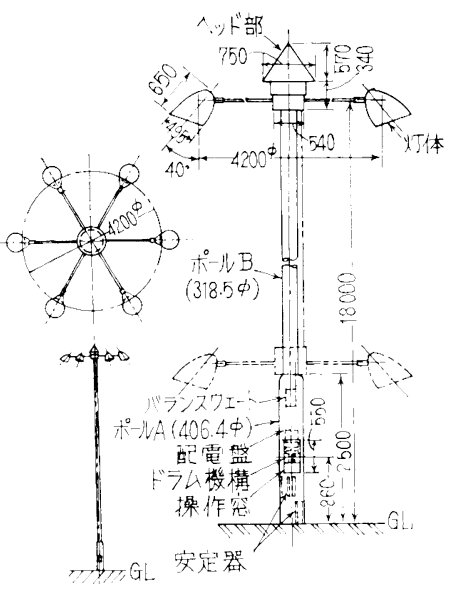

図36灯用昇降式ハイ ポール照明灯

(寸泣の瓶位 $\mathrm{mm}$ )

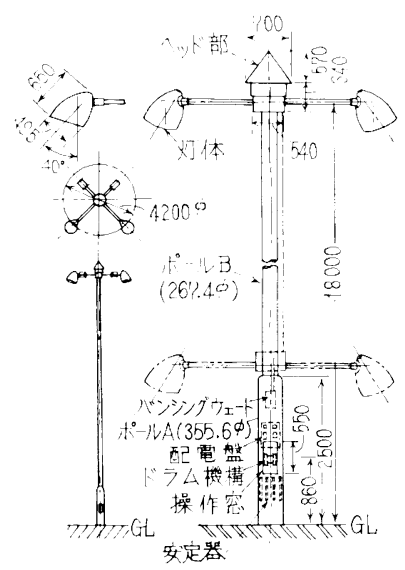

人図42灯用昇降式ハイ ポール照明灯

(小法の单位 mm) で照らし出され，明るい李ぶしさの少ない照明 が遊泳者に好評である。
施主 横浜市（港湾局）
設計 松田・平田・圾本設計事狢所
施工：清水建設侏

電気工事 扶桑電機侏

光源拉上び 東京芝浦電気侏 器具製作

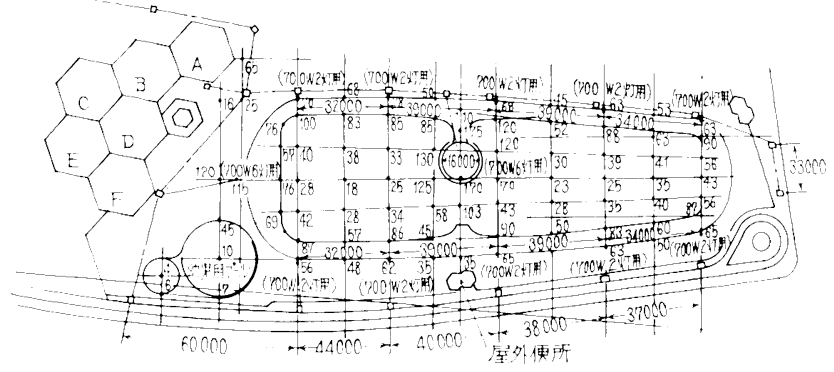

図 5 ハイポール照明灯の配置と照度分布図

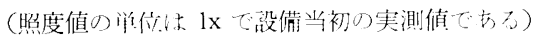

（資料提供 東芝语的制照明電材開発部） 


\section{阪急三番街 テルイ美容室の照明}
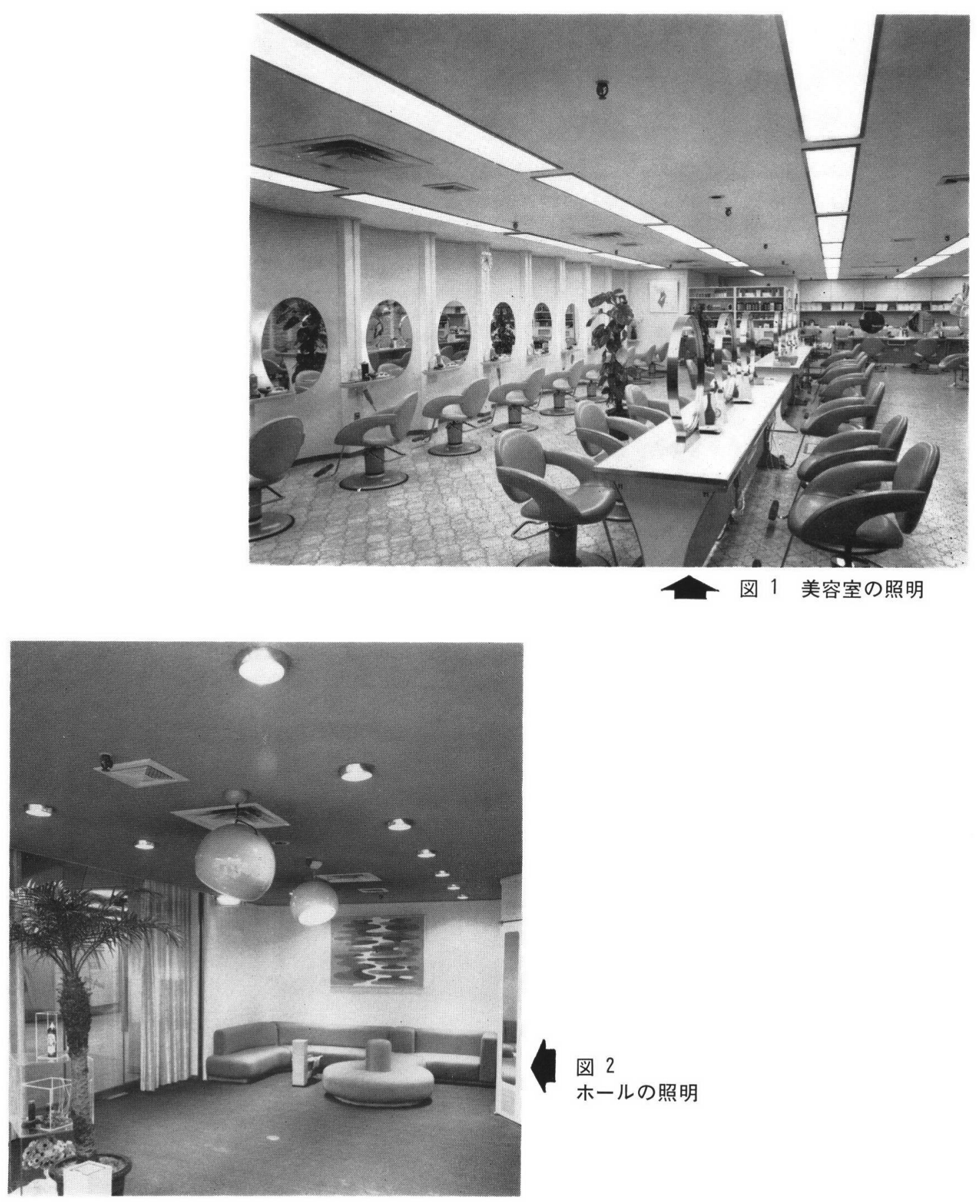


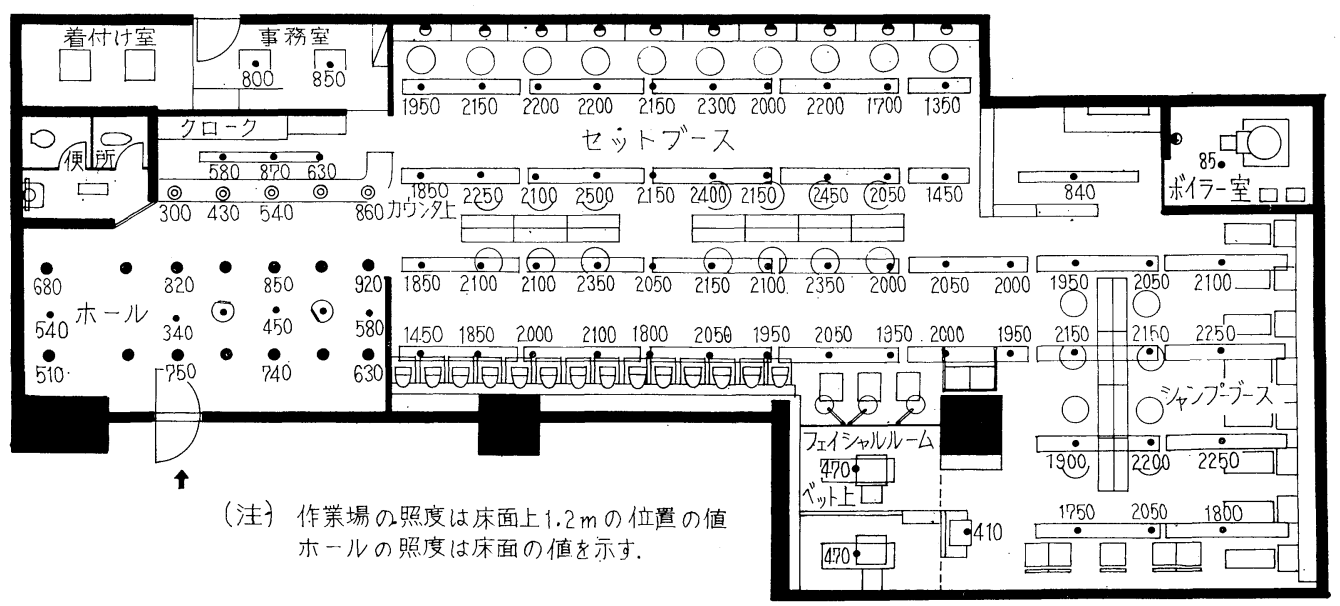

\section{図 3 照明器具配置 - 照度分布図}

\section{概 要}

国鉄大阪駅の北側に阪急新梅田駅が建設されたが，同 駅の 1 階, 地下には新しくショッピングセンター（総面 積 $518,000 \mathrm{~m}^{2}$ ) が併設され，阪急三番街 “川のある地下 街”が昭和 44 年 12 月に開場した.

テルイ美容室梅田店（床面積 $254 \mathrm{~m}^{2}$ ) もこの地下街の 一つ, オモチャと電化の町に新設され同時に開店した.

同美容室は大阪の南区に本社を構え，創 業 40 年の伝 統をもつ美容界の先達である，美容技術者には高度な技 術研修の教育の実施, 㛜格な職務規律は業界でも定評が ある。

店内の内装は床は明るい白色タイルを敷き，壁は淡い 青色, 天井は白, 美容用いすは橙色の色彩計画が行なわ れ，作業を気持ちよくするための環境造りが考えられて いる.

また，美容室としてのムードを得るためにもパーマ， セット，カットや美顔術に用いる鏡台は楕円形の鏡，円 形鏡が採用され，顔を美しく見せる工夫，さらにサービ ス面でも客を待たせないように鏡台，シャンプ台，ドラ イヤなど 66 台を完備するとともに，時間チケットの発 行, 毛髪カルテの作成を行ない保存している.

照明は技術者の作業性と健康，衛生的な環境などの見 地から重要であるが，特に黒髪は陰影がつかみにくいの で, 高照度かつ不快なまぶしさのない照明が要求され る.そのため照明は $110 \mathrm{~W}$ 高出力けい光灯埋込及形特 殊ルーバを使用し, 量と質の面にも十分に配慮されたも のとなっている.

\section{照明設備の概要}

照明設備としては，場所的に太陽光が全然入射しない 地下街であるため, 健康的, 衛生的かつ快適な環境を得る
ことに留意し，同時に美容技術者が黒髪のパーマ・セッ トなどの細かな作業を行ならための明視条件を満足させ 能率を高めるものが要求される. そのため照度は床上 1.2

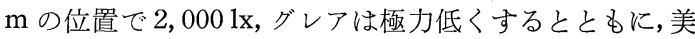
容室らしいふんい気も得られるように考慮されている.

照明器具は $110 \mathrm{~W} 2$ 灯用高出力けい光灯埋込み形々 し，下面には透明のアクリル格子ルーバが用いられてい る（図 1). また鏡台の楕円形鏡の裏面には， $40 \mathrm{~W}$ ミ 二 電球（クリア）が 4 個取り付けられ壁面を照らし，反射 された間接光で鏡を浮き上がらせ，ふんい気を高めてい る、な拈店内の鉛直面の明るさは客の顔の部分で $900 \mathrm{~lx}$ の照度を得ている．ホールは $100 \mathrm{~W}$ シールドビーム電 球のダウンライト 14 個と, $100 \mathrm{~W}$ 白熱電球大型セード 2 台により約 $700 \mathrm{~lx}$ の照度にし, 落ち着きのあるもの となっている(図 2).

照 明 器 具 $110 \mathrm{~W}$ 高出力けい光灯埋込み形下面 ルーバー26台 $40 \mathrm{~W}$ けい光灯埋込み形下面ルーバ

$$
\begin{array}{ll} 
& 2 \text { 台 } \\
\text { 二電球 } & 40 \text { 灯 }
\end{array}
$$

平均照度 作業場 $2,0401 \mathrm{x}$ (鉛直面 $9001 \mathrm{x}$ ) ホール $720 \mathrm{~lx}$
施
主 侏照井会館
建 築 設 計 吉田武藤建築研究所
内 装設 計 長谷川晶一デザイン事務所
施
工 侏竹中工務店, 木村工務店, 大和工業
電 気 工 事 大阪電気暖房侏
照明設備製作 松下工電(制)

（資料提供 松下電工秼照明事業部 LAB） 正会員 門永 鉄雄 
一滋賀県一

\section{栗東トレーニングセンター 構内道路の照明}

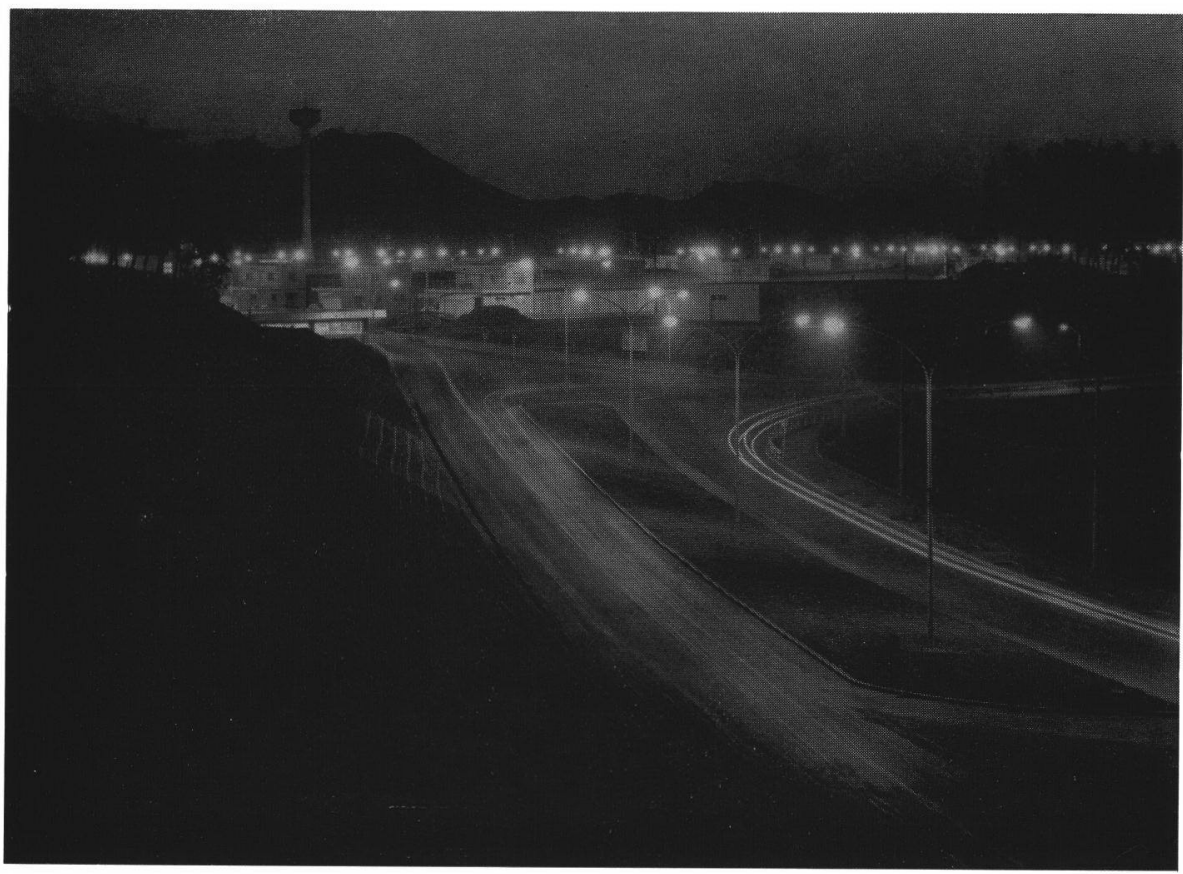

1 図 1 栗東トレーニングセンター夜景

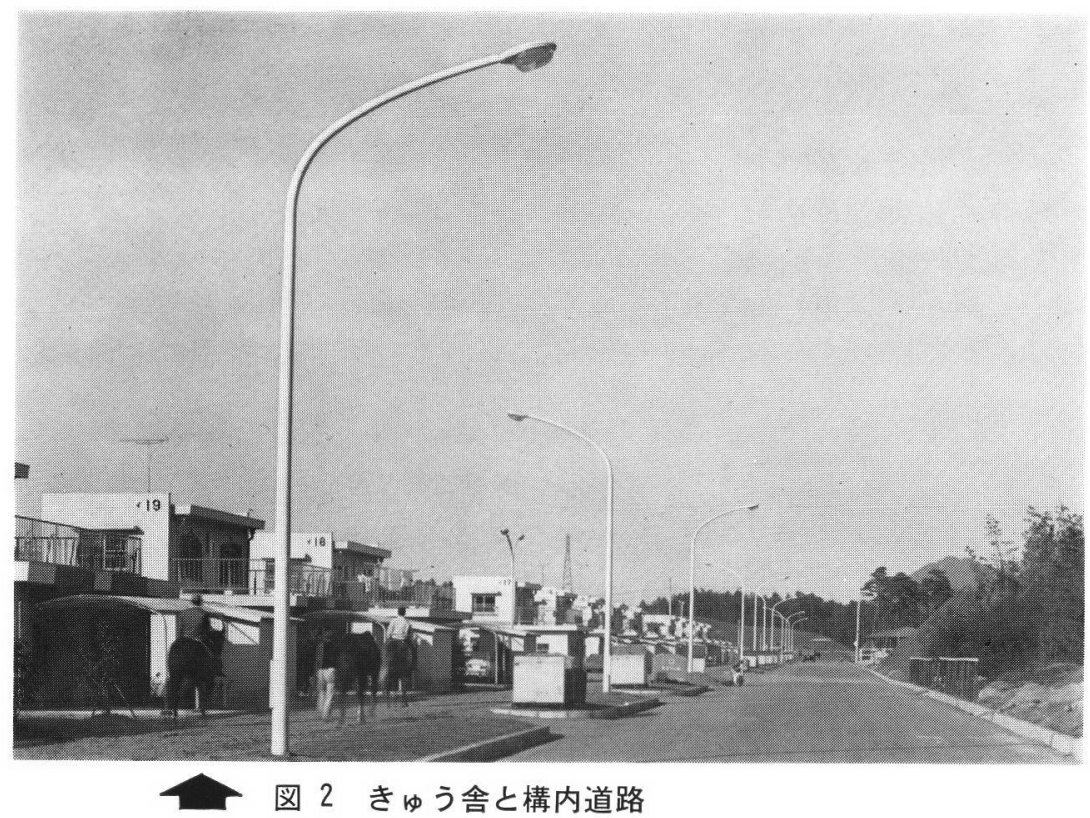




\section{概}

\section{要}

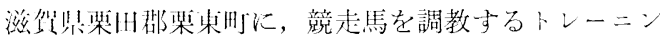
グセンターが完成した。

このトレーニングセンターは，180万平方米の㳓地に 調教馬場, きゅう含, 調教スタンド执よび関係者宿全か ら楧成され，同七ンタ一人口より調教スタンドに花る很 復 4 車線の道路は，メインストリートとなっている。 た，構内と区画し馬場ときゅう舎を結ぶ道路は，埔桨進 路と馬用砂道が併設され，分離带により分されてい る.

馬の調教は军朝より始められるので, 四倸者および热 の保安のため，同センタ一全体にわたって哭归が没借さ れている。ここでは，けい炎水銀ランンによる粠以道路 の照明を紹介する。

\section{照 明 概 要}

メインストリート (総幅门 $25 \mathrm{~m}$ ，中央分離芇幅 $9 \mathrm{~m}$ )

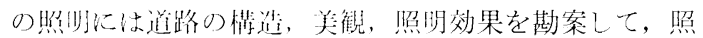
明器旦には七ミカットォフ $\mathrm{A}$ 形道路灯 $\mathrm{KSC}-7$ (光源

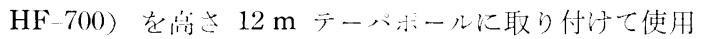

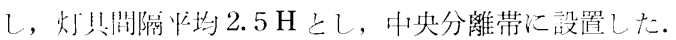

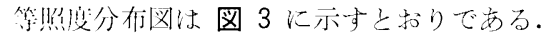

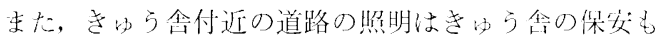
考䍐し, 舗装道路, 砂道己も, 照明器具は七ミカットな ᄀ B 形道路灯 WH-403 (光源 HF-300) を高さ $7 \mathrm{~m}$ の

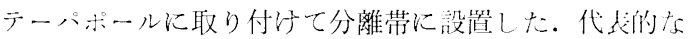
区間の等照度分布四は図 4 のよらになる。

\section{照 明 設 備 \\ 光 源けい光水銀ランソ $(\mathrm{HF}-700)$

$\begin{array}{lll}" \prime & \text { " } & (\mathrm{HF}-400) \\ " \prime & \text { " } & (\mathrm{HF}-300) \\ " 1 & \text { " } & (\mathrm{HF}-100)\end{array}$

33 個

器 具 $700 \mathrm{~W}$ 道路照四器!! $\mathrm{KSC}-7$

$400 \mathrm{~W}$ " " WH- 403

$200 \mathrm{~W}$ 街路照均器! WM-200

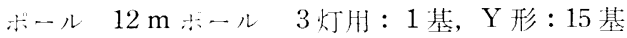

$7 \mathrm{~m}$ ポール 3 灯用 : 4 基, $\mathrm{Y}$ 形 : 146 基

基本形 : 142 基

480 個 10 個 33 台 484 台 10 台

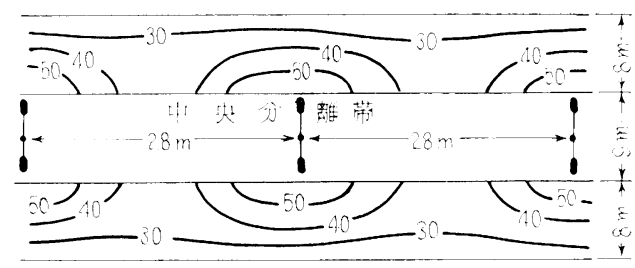

図 3 メインストリートの 等照度分布図

网中の数值法水平面照度を示与. 照明器具 $\mathrm{KSC}-7$ ( HF-700) 器具值 斜角 $15^{\circ}$ ，ポール $12 \mathrm{~m}$ テーパホー 儿 (12-28 Y), 平均照度 $34 \mathrm{~lx}$ (初期 值)
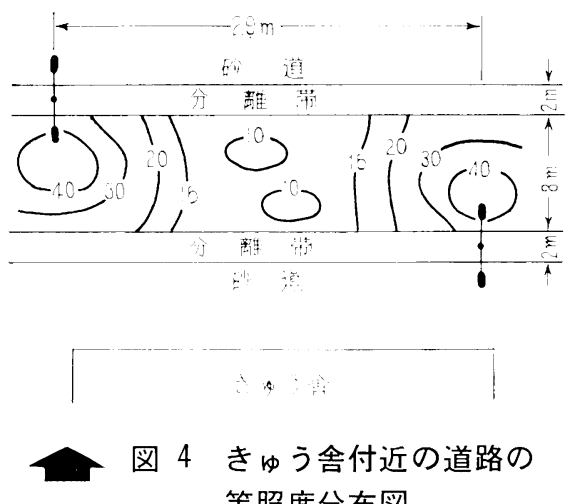
等照度分布図

因中心数值は水平面照度 (1x) を示与。 照朋器具 WH-403 (HF-300) 器具傾斜 角 $15^{\circ}$ ，ポール $7 \mathrm{~m}$ テーパホール (7-20 Y), 平均照度 $211 \mathrm{x}$ (初期值)

$5 \mathrm{~m}$ ホール自線形 : 10 基

共架 式 $2.1 \mathrm{~m}$ ケ人：4 具 $1.8 \mathrm{~m}$ ケ人: 34 非

\begin{tabular}{|c|c|}
\hline 施 & 川本川尖解胞全 \\
\hline 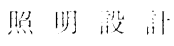 & 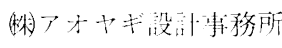 \\
\hline fet & H本電没(株) \\
\hline 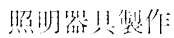 & 邑和䉓機侏 \\
\hline
\end{tabular}

